\title{
Effects of some nitrogen-fixing plants on seedling growth of scotch pine
}

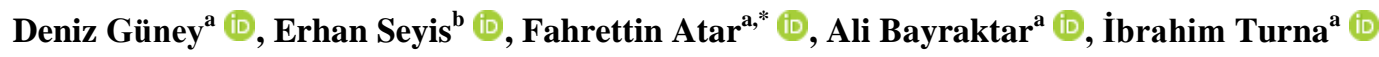

\begin{abstract}
Nitrogen is one of the most important nutrients for plants, and some plants are involved in the conversion of atmospheric nitrogen to organic form. These plants are capable of nitrogen fixing by bacteria in their roots and are important in alleviating nitrogen deficiency and improving soil. The objective of this research is to determine the growth differences in Scotch pine (Pinus sylvestris L.) seedlings grown together with some nitrogen-fixing species. The study was conducted in The Research and Application Greenhouse at Faculty of Forestry, Karadeniz Technical University. Alnus glutinosa, Robinia pseudoacacia and Vicia sativa were selected as nitrogen-fixing species. Seeds were sown, by different sowing combinations, in special sowing crates in November. For 1-year-old scotch pine seedlings after the first growing period, seedling length, root collar diameter and sturdiness quotient were determined. The results indicated that while the average length of Pinus sylvestris seedlings sown alone was $3.36 \mathrm{~cm}$, the average length of the seedlings belonging to Pinus sylvestris+Vicia sativa combination reached $6.84 \mathrm{~cm}$. Similarly, mean root collar diameter was $0.47 \mathrm{~mm}$ greater in the Pinus sylvestris+Vicia sativa sowing combination. The use of higher quality seedlings obtained through sowing combination of Pinus sylvestris+Vicia sativa can be advantageous in areas where there is a ground cover problem or the use of quality seedlings is required because of extreme conditions in terms of altitude, climate and soil.
\end{abstract}

Keywords: Seedling morphology, Pinus sylvestris, Sowing combination, Nitrogen fixation

\section{Bazı azot bağlayıcı bitkilerin sarıçam fidanlarının gelişimi üzerine etkisi}

\begin{abstract}
Özet: Bitkiler için en önemli besin elementlerinden biri azot olup atmosferik azotun organik forma dönüştürülmesinde bazı bitkiler görev almaktadır. Köklerinde bulunan bakteriler vasıtasıyla azot bağlama yeteneğinde olan bu bitkiler azot eksikliğinin hafifletilmesi ve toprağın iyileştirilmesi bakımından önem arz etmektedir. Araştırmada azot bağlayıcı bazı türlerle birlikte yetiştirilen sarıçam (Pinus sylvestris L.) fidanlarındaki gelişim farklılıklarının ortaya koyulması amaçlanmıştır. Bu çalışma Karadeniz Teknik Üniversitesi Orman Fakültesi Araştırma ve Uygulama serasında yürütülmüştür. Alnus glutinosa, Robinia pseudoacacia ve Vicia sativa türleri azot bağlayıcı tür olarak seçilmiştir. Tohumlar Kasım ayında özel ekim kasalarına farklı ekim kombinasyonlarıyla ekilmiştir. İlk vejetasyon dönemi sonrasında bir yaşındaki sarıçam fidanlarında, fidan boyu, kök boğaz çapı ve gürbüzlük indisi değerleri belirlenmiştir. Pinus sylvestris işlemine ait fidanların ortalama boyu $3.36 \mathrm{~cm}$ iken, Pinus sylvestris+Vicia sativa ekim kombinasyonuna ait fidanların ortalama boyunun $6.84 \mathrm{~cm}$ 'ye ulaştığı tespit edilmiştir. Aynı şekilde kök boğaz çapı bakımından da Pinus sylvestris+Vicia sativa ekim kombinasyonunda 0.47 mm'lik bir artış meydana geldiği görülmektedir. Özellikle diri örtü probleminin olduğu ya da rakım, iklim ve toprak özellikleri bakımından ekstrem koşullar nedeniyle kaliteli fidanların kullanılması gereken alanlarda Pinus sylvestris+Vicia sativa ekim kombinasyonu ile elde edilecek daha kaliteli fidanları kullanmak önemli bir avantaj olabilecektir.

Anahtar kelimeler: Fidan morfolojisi, Pinus sylvestris, Kombine ekim, Azot bağlama
\end{abstract}

\section{Introduction}

Nitrogen is the main ingredient of amino acids, nucleic acids and other amino compounds and polymers formed in the cells of all living creatures (Tecimen and Sevgi, 2008). Although nitrogen is among the most abundant elements in the world, it is the critical limiting element for growth of most plants because of its unavailability (Smil, 1999; Socolow, 1999; Graham and Vance, 2000). When the proportions of the elements in the structure of the plants are examined, it is seen that nitrogen is found to be lower in ratio than carbon, hydrogen and oxygen (Hasman, 1972; Haynes, 1986). While nitrogen constitutes $1.5-5 \%$ of the plant dry weight (Haynes, 1986) and is present in a very low amount in terms of quantity, it is one of the main nutrients in plant life and biochemical events of organic compounds (Haynes, 1986; Gebauer and Schulze, 1997). Nitrogen mineralization in soil in the productivity of ecosystems (Rehder, 1976; Gökçeoğlu and Rehder, 1977; Woodmansee et al., 1978; Woodmansee and Duncan, 1980; Runge, 1983; Vaughn et al., 1986; Güleryüz and Gökçeoğlu, 1994) and nitrate reductase activity in species belong to various taxonomic groups are seen as important indicators (Al Gharbi and Hipkin, 1984; Smimoff and Stewart, 1985; Lee et al., 1986; Gebauer et al., 1988; Widmann et al., 1990; Gebauer and Schulze, 1997; Güleryüz and Arslan, 1999).

Nitrogen constitutes $78 \%$ of the atmosphere with its gaseous form and has $15 \%$ share in the structure of nucleic acids, proteins and vitamins. Plants cannot use nitrogen in gaseous form. Nitrogen is converted into nitrite by nitrite

\footnotetext{
a Karadeniz Teknik Üniversitesi, Orman Fakültesi, Silvikültür Anabilim Dalı, Trabzon

b Çanakkale Onsekiz Mart Üniversitesi, Yenice Meslek Yüksekokulu, Çanakkale

@ * Corresponding author (İletişim yazarı): fatar@ktu.edu.tr

$\checkmark \quad$ Received (Geliș tarihi): 18.06.2019, Accepted (Kabul tarihi): 18.12.2019
}

Citation (Atıf): Güney, D., Seyis, E., Atar, F., Bayraktar, A., Turna, I., 2019. Effects of some nitrogen-fixing plants on seedling growth of scotch pine. Turkish Journal of Forestry, 20(4): 284-289. DOI: $10.18182 /$ tjf. 579386 
bacteria, and nitrite is converted into nitrate by nitrate bacteria and made usable by plants (İmriz et al., 2014). Symbiotic nitrogen fixation plays an important role in most forest soils. This process occurs as a result of a symbiosis between leguminous plants and bacteria of the genus Rhizobium and between Frankia bacteria, a genus of Actinomycet, and non-leguminous plants (Alnus, Myrica, Hippophae, Elaeagnus, Shepherdia, Casuarina, Coriaria and Ceanothus) (Tilki, 2002; Pritchet and Fisher, 1987; Burris, 1988; Wheeler, 1991).

Generally, 100 to $400 \mathrm{~kg}$ of N/ha/year can be supplied by biological nitrogen fixation to the forest ecosystem. Nitrogen is fixed in soil with free-living bacteria $(<15 \mathrm{~kg}$ N/ha/year), Cyanobacteria (7-80 kg N/ha/year), symbiotic life of Frankia bacteria and non-leguminous species (2-362 $\mathrm{kg} \mathrm{N} /$ ha/year), and Rhizobium bacteria and leguminous species (24-584 kg N/ha/year) (Elkan, 1992; FAO, 1993). Some plants that are capable of nitrogen fixation through the bacteria in their roots are used for the alleviation of nitrogen deficiency and soil improvement in forestry in some countries, especially in European countries, Australia and the USA. Plants with nitrogen-fixing bacteria help improve poor soils and enrich plant nutrients (Diagne et al., 2013; Stokdyk and Herrman, 2014). These plants also contribute to the development of other species in the afforestation studies by providing nitrogen support (Miller and Murray, 1978; Voigtlaender et al., 2012; Mortimer et al., 2015).

In some studies about nitrogen fixation, it were determined that $10.6 \mathrm{~kg} / \mathrm{ha} /$ year fixation in Myrica gale (Permar and Fisher, 1983) and $62 \mathrm{~kg} / \mathrm{ha} /$ year fixation in Alnus rubra (Tripp et al., 1979). With reference to Pritchet and Fisher (1987) and FAO (1993) in the study of the amount of nitrogen fixation in relation to some species, Tilki (2002) stated that Alnus glutinosa, Casuarina equisetifolia, Elaeagnus sp., Robinia pseudoacacia, Hippophae sp. and Wax myrtle fix nitrogen as <56, 60-200, $<15,100-200,2-180$ and $<132 \mathrm{~kg} / \mathrm{ha} /$ year, respectively. In the mixed grown plantations with Alnus rubra in previous studies conducted by Miller and Murray (1978) and Debell and Radwan (1979), they investigated the increments of Pseudotsuga menziesii (Mirb.) Franco and Populus trichocarpa Torr. Additionally, biomass developments in Pinus tunbergii Parl. (Moffat, 2000), poplar (Van der Meiden, 1961) and Pseudotsuga menziesii plantation (Binkley et al., 1984) grown together with alder were researched. Moreover, Ashby and Baker (1968), Turvey and Smethurst (1983) studied the effects of Robinia pseudoacacia on the development of its mixed plantations with coniferous and deciduous species.

Symbiotically fixing nitrogen can be transformed into available form for plants, thus helping reduce nitrogen fertilizer costs and prevent environmental pollution during the use of chemical fertilizers. The aim of this study was to determine the growth differences in Pinus sylvestris L. seedlings grown together with some nitrogen-fixing species.

\section{Material and methods}

\subsection{Study area}

The present study was carried out in The Research and Application Greenhouse at Faculty of Forestry, Karadeniz Technical University. Alnus glutinosa (A.glu), Robinia pseudoacacia (R.pse) and Vicia sativa (V.sat) were selected as nitrogen-fixing species. Seeds of the species used in the study were obtained from Trabzon region (Figure 1), and sown in open field conditions. Additionally, the climate data between 1927 and 2018 belonging to Trabzon province, where Karadeniz Technical University is located, are given in Table 1. According to the long-term climate data of the area where the open field nursery is located, the annual average temperature is $14.7{ }^{\circ} \mathrm{C}$ and the total annual precipitation is $820.7 \mathrm{~mm}$.

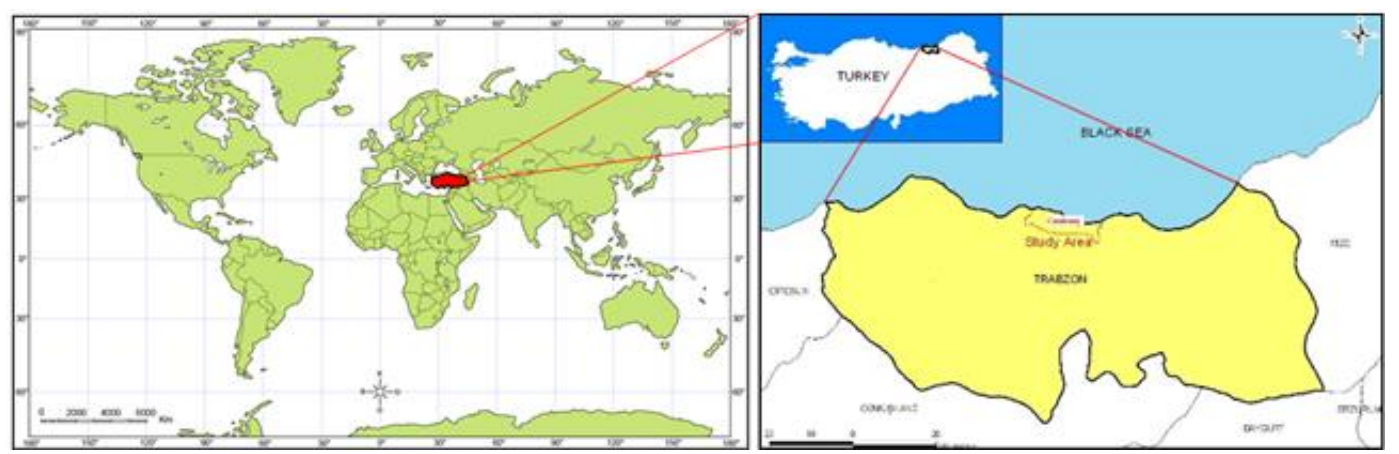

Figure 1. Geographical location of study area in Karadeniz Technical University

Table 1 . The average meteorological values of the study area

\begin{tabular}{|c|c|c|c|c|c|c|c|c|c|c|c|c|}
\hline & \multicolumn{12}{|c|}{ Climate Period (1927-2018) } \\
\hline & Jan & Feb & Mar & Apr & May & Jun & Jul & Aug & Sep & Oct & Nov & Dec \\
\hline 1 & 7.3 & 7.3 & 8.4 & 11.7 & 16.0 & 20.3 & 23.1 & 23.5 & 20.3 & 16.6 & 12.8 & 9.5 \\
\hline 2 & 10.7 & 10.8 & 11.9 & 15.5 & 19.1 & 23.1 & 25.9 & 26.5 & 23.7 & 20.0 & 16.5 & 12.9 \\
\hline 3 & 4.6 & 4.3 & 5.4 & 8.7 & 12.9 & 17.0 & 19.9 & 20.4 & 17.3 & 13.6 & 10.0 & 6.7 \\
\hline 4 & 2.7 & 3.3 & 3.4 & 4.4 & 5.5 & 7.1 & 5.9 & 5.6 & 4.9 & 4.5 & 3.7 & 2.7 \\
\hline 5 & 12.5 & 12.4 & 13.3 & 12.9 & 12.8 & 10.8 & 8.0 & 8.8 & 11.2 & 12.6 & 12.1 & 12.7 \\
\hline 6 & 82.4 & 63.7 & 58.7 & 56.8 & 51.8 & 50.1 & 35.4 & 44.9 & 79.5 & 115.0 & 98.9 & 83.5 \\
\hline
\end{tabular}

1. Avg. Temperature $\left({ }^{\circ} \mathrm{C}\right) ;$ 2. Avg. Highest Temperature $\left({ }^{\circ} \mathrm{C}\right) ; 3$. Avg. Lowest Temperature $\left({ }^{\circ} \mathrm{C}\right) ;$. Avg. Sunshine Time (hour); 5. Avg. Number of Rainy Days; 6 . Monthly Total Precipitation Avg. (mm) 


\subsection{Experimental design and nursery treatment}

Sowing of seeds was carried out in open field conditions of the research area. For the seeds sown in November, completely randomized design was used. Special sowing crates were prepared in order to eliminate soil effects in the external environment in the process of sowing of seeds and to determine the effects of nitrogen-fixing species on the growth of scotch pine seedlings. These were prepared as $1.2 \times 0.6 \mathrm{~m}$ sizes and $30 \mathrm{~cm}$ deep. Control (only sowing of scotch pine) and four different sowing combinations were conducted as three repetitions in sowing crates. As sowing medium, the coarse gravel was laid on the bottom of the crates where the seeds were sown and then fine grained gravel was laid on top of it. Additionally, the unsieved forest soil was cleaned from foreign materials and laid on the fine gravel and finally, covered with sieved forest soil and made ready for sowing. Sowing in row of seeds were conducted by opening the lines. The schematic representation of the trial design used for sowing seeds is given in Figure 2.

In this study, a total of 2100 seeds were sown to seedbed using 300 seeds for each species in each treatment. As specified in the trial design in Figure 2, 300 seeds for P.syl, 600 seeds for P.syl+A.glu, 600 seeds for P.syl+R.pse and 600 seeds for P.syl+V.sat were used.

For 1-year-old seedlings grown in the crates after first vegetation period, seedling length (SdL), root collar diameter (RCD) and sturdiness quotient (SQ) were determined. 1350 seedlings $(3 \times 50$ seedlings from each treatment) were used for measurements (Figure 3 ). The sturdiness quotient attributes to the ratio of the length of the seedling to the root collar diameter and expresses the vigour and robustness of the seedling (Thompson, 1985; Aldhous, 1994; Jaenicke, 1999).

\subsection{Data analysis}

Data were analysed using the SPSS 23.0 statistical program. The analyses included ANOVA and Bonferroni Test. Oneway analysis of variance is used to test the equality of $\mathrm{k}$ independent groups averages taken from $\mathrm{k}$ population showing the normal distribution (Ercan, 1997; Özdamar, 1999; Özkan, 2003). In addition, the statistical significance of the differences between the results of different sowing combinations with the Bonferroni test was demonstrated.

\section{Result and discussion}

The results of the analysis of variance, mean and standard deviation related to sowing combinations are given in Table 2. According to the results of the analysis of variance, there were statistically significant differences $(P<0.01)$ among the sowing combinations in terms of all measured morphological characters. The average seedling length for P.syl was determined as $3.36 \mathrm{~cm}$, while the average values for, P.syl+A.glu, P.syl+V.vat and P.syl+R.pse occurred as $6.25 \mathrm{~cm}, 6.84 \mathrm{~cm}$ and $5.53 \mathrm{~cm}$ respectively. On the other hand, while the average root collar diameter for P.syl seedlings was $1.29 \mathrm{~mm}$, the average values for P.syl+A.glu, P.syl+V.vat and P.syl+R.pse were determined as $1.46 \mathrm{~mm}, 1.76 \mathrm{~mm}$ and
$1.15 \mathrm{~mm}$ respectively. The sturdiness quotient, was 2.67 for P.syl, 4.38 for P.syl+A.glu, 3.98 for P.syl+V.vat and 4.91 for P.syl+R.pse. The differences between SdL, RCD and SQ values depending on the sowing combinations are shown in Figure 4.

Pinus sylvestris seedlings obtained by sowing combinations had high growth than the seedlings acquired by control seeds, especially in terms of seedling length. Compared to seedlings in control, more seedling length values were acquired to be $103.6 \%$ for seedlings obtained from P.syl+V.vat sowing combination, $86.0 \%$ for P.syl+A.glu and $64.6 \%$ for P.syl+R.pse. RCD occurred as lower for the seedlings from P.syl+R.pse sowing combinations compared to P.syl seedlings in control, while it was higher for the seedlings from P.syl+A.glu and P.syl+V.vat sowing combinations. Also, it was determined that the seedlings from all mixed sowing combinations produced a higher ratio than the seedlings in control in terms of sturdiness quotient (Table 2).

The significance of differences between sowing combinations related to measured morphological characteristics was determined by Bonferroni test and the results are shown in Table 3.

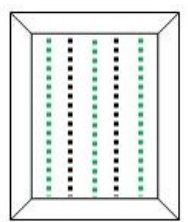

P.syl+A.glu

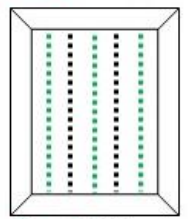

P.syl+V.sat

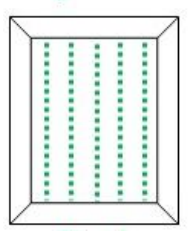

P.syl

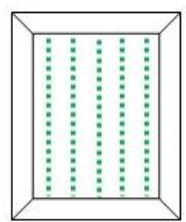

P.syl

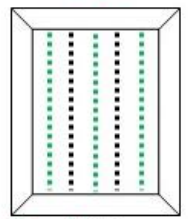

P.syl+R.pse

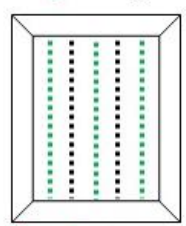

P.syl+A.glu
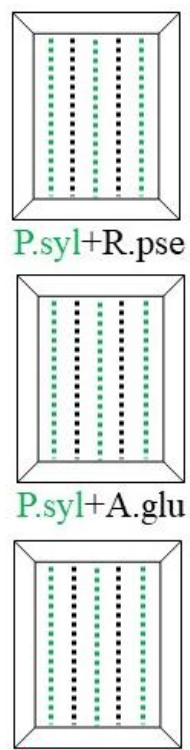

P.syl+V.sat

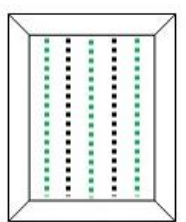

P.syl+V.sat

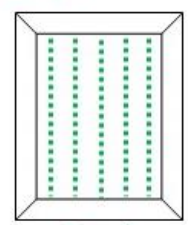

P.syl

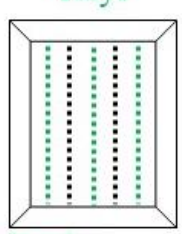

P.syl+R.pse
Figure 2. Trial design related to sowing combinations

$\underline{\text { Table 2. ANOVA results related to sowing combinations }}$

\begin{tabular}{lccc}
\hline & SdL $(\mathrm{cm})$ & RCD $(\mathrm{mm})$ & SQ \\
\hline P.syl & $3.36 \pm 0.86$ & $1.29 \pm 0.31$ & $2.67 \pm 0.72$ \\
P.syl+A.glu & $6.25 \pm 1.32$ & $1.46 \pm 0.28$ & $4.38 \pm 1.01$ \\
P.syl+V.vat & $6.84 \pm 1.56$ & $1.76 \pm 0.45$ & $3.98 \pm 0.86$ \\
P.syl+R.pse & $5.53 \pm 1.40$ & $1.15 \pm 0.29$ & $4.91 \pm 1.25$ \\
\hline F & 51.471 & 48.770 & 38.713 \\
P & 0.000 & 0.000 & 0.000 \\
\hline
\end{tabular}



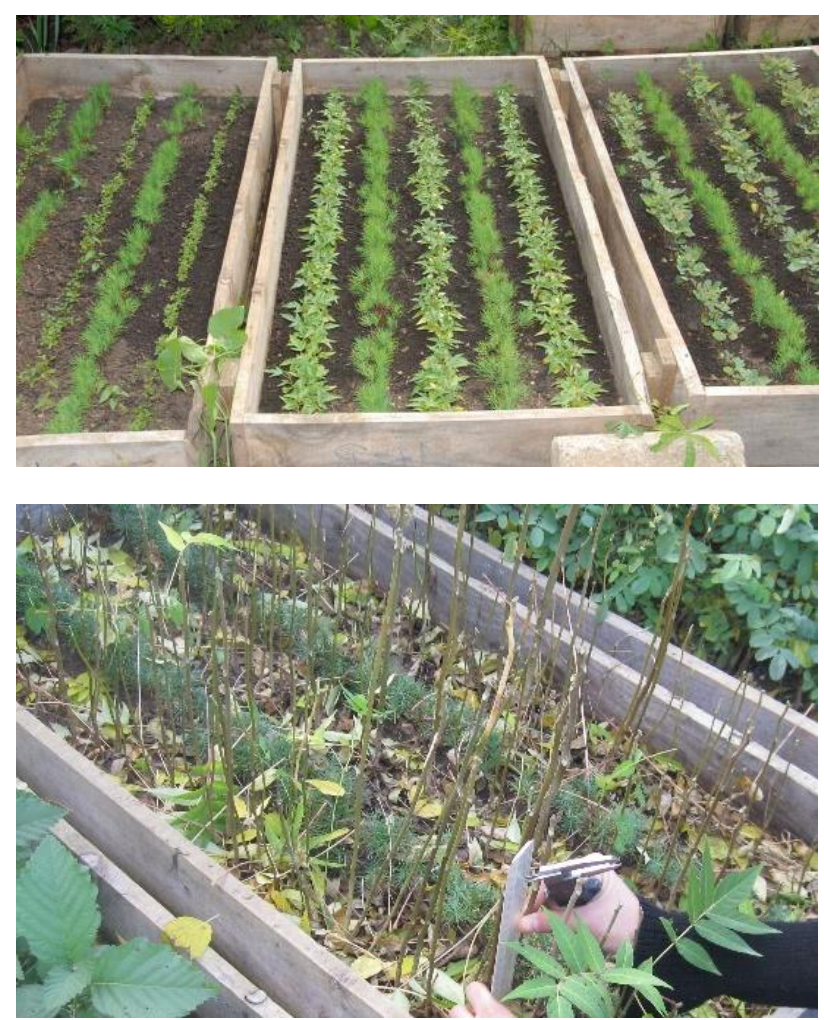

Figure 3. Different sowing combinations and morphological measurements of seedlings

Table 3. The results of Bonferroni test with respect to sowing treatments

\begin{tabular}{clccc}
\hline \multirow{2}{*}{ Tree species } & \multicolumn{3}{c}{ Mean difference } \\
\cline { 2 - 5 } & & SdL $(\mathrm{cm})$ & RCD $(\mathrm{mm})$ & SQ \\
\hline \multirow{2}{*}{ P.syl } & P.syl+A.glu & $-2.89^{*}$ & -0.17 & $-1.71^{*}$ \\
& P.syl+V.vat & $-3.48^{*}$ & $-0.47^{*}$ & $-1.31^{*}$ \\
& P.syl+R.pse & $-2.17^{*}$ & 0.14 & $-2.23^{*}$ \\
\hline \multirow{2}{*}{ P.syl+A.glu } & P.syl & $2.89^{*}$ & 0.17 & $1.71^{*}$ \\
& P.syl+V.vat & -0.58 & $-0.30^{*}$ & 0.40 \\
& P.syl+R.pse & $0.72^{*}$ & $0.31^{*}$ & $-0.53^{*}$ \\
\hline \multirow{2}{*}{ P.syl+V.vat } & P.syl & $3.48^{*}$ & $0.47^{*}$ & $1.31^{*}$ \\
& P.syl+A.glu & 0.58 & $0.30^{*}$ & -0.40 \\
& P.syl+R.pse & $1.31^{*}$ & $0.61^{*}$ & $-0.93^{*}$ \\
\hline \multirow{2}{*}{ P.syl+R.pse } & P.syl & $2.17^{*}$ & -0.14 & $2.23^{*}$ \\
& P.syl+A.glu & $-0.72^{*}$ & $-0.31^{*}$ & $0.53^{*}$ \\
& P.syl+V.vat & $-1.31^{*}$ & $-0.61^{*}$ & $0.93^{*}$ \\
\hline
\end{tabular}
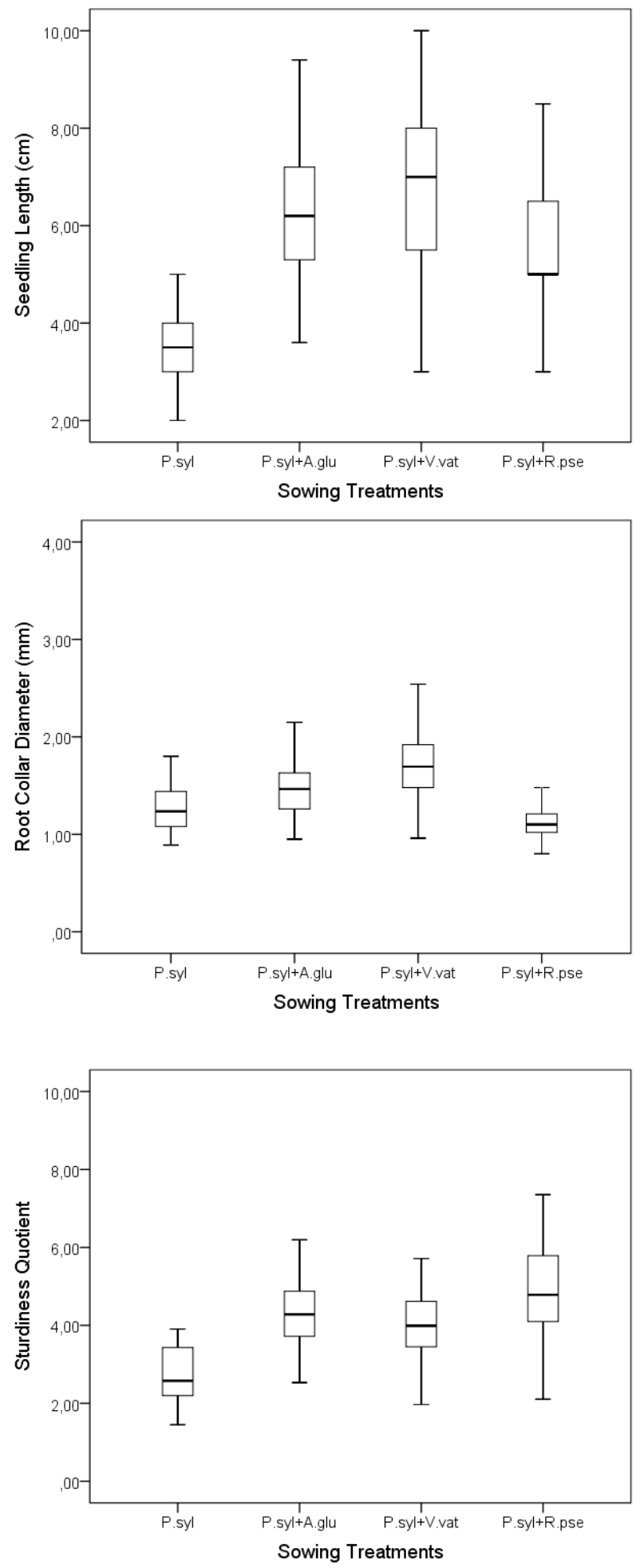

Figure 4. The results of SdL, RCD and SQ according to sowing combinations 
The maximum length difference $(3.48 \mathrm{~cm})$ in terms of seedling length occurred between P.syl and P.syl+V.vat sowing combinations. While especially the average length of the seedlings belonging to P.syl is $3.36 \mathrm{~cm}$, it is noteworthy that the average length of the seedlings belonging to P.syl+V.vat sowing combination reaches 6.84 $\mathrm{cm}$. Similarly, an increase of $0.47 \mathrm{~mm}$ was observed in the P.syl+V.vat sowing combination in terms of the root collar diameter. For the P.syl+A.glu sowing combination, it was found that the average seedling length was $2.89 \mathrm{~cm}$, the average root collar diameter was $0.17 \mathrm{~mm}$ more than the values of P.syl. In the previous studies, it was determined that the better increments occurred as 59\% for Pseudotsuga menziesii (Mirb.) Franco (Miller and Murray, 1978), as 50\% for Populus trichocarpa Torr. and Gray (DeBell and Radwan, 1979) in mixed grown plantations with Alnus rubra Bong. compared to the purely grown plantations. In other studies, that were investigated the effects of alder on the species grown together with it thanks to nitrogen-fixing ability, it was reported that biomass development increased in Pinus tunbergii Parl. (Moffat, 2000), poplar plantation (Van der Meiden, 1961) and Pseudotsuga menziesii plantation (Binkley et al., 1984). Instead of pure plantation of Populus trichocarpa, as a result of grown together of $P$. trichocarpa and Alnus rubra species were accomplished more yield (Tarrant, 1983; Binkley et al., 1984). As a result of growing together with Pseudutsuga menziesii of Alnus rubra, together with coniferous and deciduous species of Alnus glutinosa, it is stated that the amount of nitrogen in the soil and the growth rate in parallel increase (Permar and Fisher, 1983; Turvey and Smethurst, 1983; Wheeler and Miller, 1990). In a study conducted by Miller and Murray in 1978, Alnus rubra was planted to 4-year-old Pseudotsuga menziesii plantation which tree growth is limited due to insufficient available nitrogen. As a result of the study, the total volume of the mixed plantation was nearly twice compared to the pure Pseudotsuga menziesii plantation. However, there are also studies indicating that the naturally grown Alnus rubra adversely affect the individuals in plantation area depending on the intensity of the species and competition occurring in the area (Radosevich et al., 2006). In another study, it was reported that both alder percentage and distance between species were effective in height growth for poplars in short-rotated cultures where alderpoplar mixture is dense. It was determined by regression analysis that there was a significant increase in the poplar height of 3 years with the increase of alder in the mixture and decrease in the height with the increase in the planting distance between poplar and alder (Hansen and Dawson, 1982).

The seedlings belonging to P.syl+R.pse sowing combinations had more height increments with $2.17 \mathrm{~cm}$, compared to the seedlings obtained from P.syl in this study. Robinia pseudoacacia is used to stabilize nitrogen-poor areas, eroded lands and coal residues in Europe (Sprent and Sprent, 1990). Similarly, Acacia cyanophylla has been used in Greece for sand dune stabilization, Acacia holoserica has been used in Australia for the improvement of coal residual areas (Nakos, 1977; Langkamp et al., 1979). Ashby and Baker (1968), Turvey and Smethurst (1983) reported that Robinia pseudoacacia has a positive effect on the development of its mixed plantations with coniferous and deciduous species, it also increases especially height growth of Juglans nigra, Liriodendron tulipifera, Acer saccharinum, Quercus rubra and Maclura pomifera. However, considering the fact that $R$. pseudoacacia is a fast growing species, it was stated that it would be beneficial to bring under the coniferous species in order not to adversely affect the coniferous species in which mixed planting is done, or to grow them together with fast growing deciduous species (Turvey and Smethurst, 1983). In another study used of Alnus glutinosa and Robinia pseudoacacia as nitrogen fixing species in order to investigate growth performance of 14-year-old Juglans nigra plantation, it was found that both the amount of soil nitrogen concentration and, the diameter and height of Juglans nigra increased (Friedrich and Dawson, 1984).

From this point of view, it can be a significant advantage to use quality seedlings to be obtained with sowing combination of Pinus sylvestris and Vicia sativa in extreme areas, especially where there is a ground cover problem or extreme ecological conditions. For the further researches, it can be suggested to grow Pinus sylvestris plantations with annual nitrogen-fixing plants such as Vicia sativa in areas where ecological conditions are difficult.

\section{References}

Aldhous, J.R., 1994. Nursery policy and planning. In: Forest Nursery Practice. (Ed: Aldhous, J.R., Mason, W.L.) Forestry Commission Bulletin, HMSO, London, UK, pp. 1-12.

Al Gharbi, A., Hipkin, C.R., 1984. Studies on nitrate reductase in British angiosperms. I. Comparison of nitrate reductase activity in ruderal, woodland edge and woody species. New Phytol. 7, 629639.

Ashby, W.C., Baker, M.B., 1968. Soil nutrients and tree growth under black locust and shortleaf pine overstories in strip-mine plantings. 1. For, 66: 66-71.

Binkley, D., Lousier, J.D., Cromack, K., 1984. Ecosystem effects of Sitka alder in a Douglas-fir plantation. Forest Sci, 30(1): 26-35.

Burris, R.H., 1988. Biological nitrogen fixation: A scientific perspective. Plant Soil, 108: 7-14.

DeBell, D.S., Radwan, M.A., 1979. Growth and nitrogen relations of coppiced black cottonwood and red alder in pure and mixed plantations. Bot. Gaz., 140: 97-101.

Diagne, N., Arumugam, K., Ngom, M., Nambiar-Veetil, M., Franche, C., Narayanan, K.K., Laplaze, L., 2013. Use of Frankia and actinorhizal plants for degraded lands reclamation. Hindawi Publishing Corporation, BioMed Research International, 2013: 1-9.

Elkan, G.H., 1992. Biological nitrogen systems in tropical ecosystems: An overview. In: Biological Nitrogen Fixation and Sustainability of Tropical Agriculture (Ed: Mulongoy, K., Gueye, M., Spencer, D.S.C.), John Wiley\&Sons, Chichester. UK, pp. 27-40.

Ercan, M., 1997. Bilimsel Araştırmalarda İstatistik. Genişletilmiş İkinci Baskı, Orman Bakanlığı, Kavak ve Hızlı Gelişen Tür Orman Ağaçları ve Araştırma Enstitüsü Müdürlüğü, İzmit.

FAO, 1993. Technical Handbook of Symbiotic Nitrogen Fixation. Legume/Rhizobium, Food and Agriculture Organization of the United Nations, Rome.

Friedrich, J.M., Dawson, J.O., 1984. Soil nitrogen concentration and Juglans nigra growth in mixed plots with nitrogen-fixing Alnus, Elaeagnus, Lespedeza, and Robinia species. Canadian Journal of Forest Research, 14(6): 864-868.

Gebauer, G., Rehder, H., Wollenweber, B., 1988. Nitrate, nitrate reduction and organic nitrogen in plants from different ecological and taxanomic groups of Central Europea. Oecologia, 75, 371-385.

Gebauer, G., Schulze, E.D., 1997. Nitrate Nutrition of Central European Forest Trees. In: Trees-Contributions to Modern Tree Physiology (Ed: Rennenberg, H., Eschrich, W., Ziegler, H.), SPB Academic Publ. The Hahue. pp. 273-291.

Gökçeoğlu, M., Rehder, H., 1977. Nutrient turnover studies in alpine ecosystems. III. Communities of lower altitudes dominated by Carex sempervirens Vill. and Carex ferroginea Scop. Oecologia, 28: 317-331. 
Graham, P.H., Vance, C.P., 2000. Nitrogen fixation in perspective: An overview of research and extension needs. Field Crops Research, 65: 93-106.

Güleryüz, G., Gökçeoğlu, M., 1994. Uludağ (Bursa) alpin bölgesi bazı bitki topluluklarında mineral azot oluşumu ve yıllık verimlilik. Turkish Journal of Botany, 18: 65-72.

Güleryüz, G., Arslan, H., 1999. Nitrate reductase activity in Verbaseum L. (Scrophulariaeea) species from the Eastem Meditterranean in dependence on altitude. Tr. J. of Botany, 23: 89-96.

Hansen, E.A., Dawson, J., 1982. Effect of Alnus glutinosa on hybrid Populus height growth in a short-rotation intensively cultured plantation. Forest Science, 28(1): 49-59.

Hasman, M., 1972. Bitkilerin Metabolizma Fizyolojisi. İstanbul Üniversitesi Yayınları, İstanbul.

Haynes, R.J., 1986. Uptake and assimilation of mineral nitrogen by plants. In: Mineral Nitrogen in the plant-soil system. (Ed: Haynes, R.J.) Academic Press. London and Orlando, pp. 303-362.

İmriz, G., Özdemir, F., Topal, İ., Ercan, B., Taş, M.N., Yakıșır, E., Okur, O., 2014. Bitkisel üretimde bitki gelişsimini teşvik eden rizobakteri (PGPR)'ler ve etki mekanizmaları. Elektronik Mikrobiyoloji Dergisi, 12(2): 1-19.

Jaenicke, H., 1999. Good tree nursery practices: Practical guidelines for research nurseries. World Agroforestry Centre. ICRAF, Majestic Printing Works, Nairobi.

Langkamp, P.J., Swinden, L.B., Dalling, M.J., 1979. Nitrogen fixation by Acacia holoserica on areas restored after mining of Grooke Eylandt Northern Territory. Australian Journal of Botany, 27: 353361.

Lee, I.A., Woodin, S.L., Press, M.C., 1986. Nitrogen assimilation in an ecological concept. In: Fundamental Ecological and Agricultural Aspects of Nitrogen Metabolism in Higher Plants (Ed.: Lambers, H., Neetson, J.J., Stulen, I.), Martinus Nijhoff Publ. Dordreeht Boston Lancester, pp. 331-346.

Miller, R.E., Murray, M.D., 1978. The effect of red alder on growth of Douglas fir. In utilization and management of alder. USDA Forest Service General Technical Report, PNW-70.

Moffat, A.J., 2000. Effects of inoculation with Frankia on the growth and nutrition of alder species and interplanted Japanese larch on restored mineral workings. Forestry, 73(3): 215-223.

Mortimer, P.E., Gui, H., Xu, J., Zhang, C., Barrios, E., Hyde, K.D., 2015. Alder trees enhance crop productivity and soil microbial biomass in tea plantations. Applied Soil Ecology, 96: 25-32.

Nakos, G., 1977. Acetylene Reduction (N2-Fixation) by Nodules of Acacia cyanophylla. Soil Biology and Biochemistry, 9: 131-133.

Özdamar, K., 1999. Paket Programlar ile İstatistiksel Veri Analizi SPSS MINITAP, Dördüncü Baskı, Kaan Kitapevi, Eskișehir.

Özkan, Y., 2003. Uygulamalı İstatistik 2. Sakarya Üniversitesi, Birinci Baskı, İktisadi ve İdari Bilimler Fakültesi, Sakarya Kitapevi, İstanbul.

Permar, T.A., Fisher, R.F., 1983. Nitrogen fixation and accretion by wax myrtle (Myrica Cerifera) in slash pine (Pinus elliottii) plantations. Forest Ecology and Management, 5: 39-46.

Pritchett, W.L., Fisher, R.F., 1987. Properties and Management of Forest Soils. John Wiley\& Sons Inc, New York

Radosevich, S.R., Hibbs, D.E., Ghersa, C.M., 2006. Effects of species mixtures on growth and stand development of Douglas-fir and red alder. Canadian Journal of Forest Researches, 36: 768-782.

Rehder, H., 1976. Nutrient turnover studies in alpine ecosystems. II. Phytomass and nutrient relations in the Caricetum firmae. Oecologia, 24: 49-62.

Runge, M., 1983. Physiology and ecology of nitrogen nutrition. In: Encyclopedia of Plant Physiology (Ed: Lange, O.L., Nobel, P.S., Osmond, P.B., Ziegler, H.), Springer-Verlag, New York, pp. 164200 .
Smil, V., 1999. Nitrogen in crop production. Glob Biogeol Cycl, 13: 647-662.

Smimoff, N., Stewart, G.R., 1985. Nitrate assimilation and translocation by higher plants. Comparative physiology and ecological consequences, Physiologia plantarum, 64: 133-140.

Socolow, R.H., 1999. Nitrogen management and the future of food: Lessons from the management of energy and carbon. Proceedings of the National Academy of Sciences, 96: 6001-6008.

Sprent, J.I., Sprent, P., 1990. Nitrogen Fixing Organisms Pure and Applied Aspects. 2nd. ed. Chapman and Hall, Cambridge, London.

Stokdyk, J.P., Herrman, K.S., 2014. Short-term impacts of Frangula alnus litter on forest soil properties. Water, Air, \& Soil Pollution, 225: 2000.

Tarrant, R.F., 1983. Nitrogen Fixation in North American Forestry: Research and Application. In: Biological Nitrogen Fixation in Forest Ecosystems: Foundations and Applications (Ed:Gordon, J.C., Wheeler, C.T.) M. Nijhoff, pp. 260-279.

Tecimen, H.B., Sevgi, O., 2008. Nitrogen transformations within forest soils by microorganisms. Süleyman Demirel Üniversitesi Orman Fakültesi Dergisi, 1: 179-189.

Thompson, B.E., 1985. Seedling morphological evaluation- What you can tell by looking. In: Evaluating seedling quality: Principles, procedures, and predictive abilities of major tests (Ed: Duryea. M.L.), Forest Research Laboratory, Oregon State University, Corvallis, OR), pp. 59-71.

Tilki, F., 2002. Biyolojik azot bağlanmasının ormancılıktaki önemi ve kullanımı. İstanbul Üniversitesi, Orman Fakültesi Dergisi, Seri B, 52,1 .

Tripp, L.N., Bezdick, D.F., Heilman, P.L., 1979. Seasonal and diurnal patterns and rates of nitrogen fixation by young red alder. Forest Science, 25: 371-380.

Turvey, N.D., Smethurst, P.J., 1983. Nitrogen Fixing Plants in Forest Plantation Management. In: Biological Nitrogen Fixation in Forest Ecosystems: Foundations and Applications (Ed: Gordon, J.C., Wheeler, C.T.) Martinus Nijhoff Publ. The Hague, pp. 261-277.

Van Der Meiden, H.H., 1961. Alder in mixture with poplar. Nederlands bosbouw tiddschrift, 33: 168-171.

Vaughn, C.A., Center, D.M., Jones, M.B., 1986. Seasonal fluctuations in nutrient availability in some Northern California annual range soils. Soil Science, 141(1): 43-51.

Voigtlaender, M., Laclau, J.P., de Moraes Gonçalves, J.L., de Cássia Piccolo, M., Moreira, M.Z., Nouvellon, Y., Ranger, J., Bouillet, J.P., 2012. Introducing Acacia mangium trees in Eucalyptus grandis plantations: consequences for soil organic matter stocks and nitrogen mineralization. Plant and Soil, 352(1-2): 99-111.

Wheeler, C.T., Miller, M.I., 1990. Current and Potential Uses of Actinorhizal Plants in Europe. In: The Biology of Frankia and Actinorhizal Plants (Ed: Schwinter, C.R., Tjepkema J.D.), Academic Press, San Diego, California, pp. 365-389.

Wheeler, C.T., 1991. Symbiotic Nitrogen Fixation. In: Physiology of Tree (Ed: Raghavendra, A.S.) J. Wiley\&Sons, Inc., New York, pp. 111-136.

Widmann, K., Gebauer, G., Rehder, H., Ziegler, H., 1990. Biomass production and nitrogen contents of the CAM plants Kalanchoe daigremontiana and $K$. tubiflora in cultures with different nitrogen and water supply. Oecologia, 82: 478-483.

Woodmansee, R.G. Dodd, J.L. Bowman, R.A. Clark, F.E., Dickinson, C.E., 1978. Nitrogen budget of a shortgrass prairie ecosystem. Oecologia, 34: 363-376.

Woodrnansee, R.G., Duncan, D.A., 1980. Nitrogen and phosphorus dynamics and budgets in annual grasslands. Ecology, 61(4): 893904. 